\title{
Evidence of natural hybridization and introgression in Bulbophyllum involutum Borba, Semir \& F. Barros and B. weddellii (Lindl.) Rchb. f. (Orchidaceae) in the Chapada Diamantina, Brazil, by using allozyme markers
}

\author{
CECÍLIA O. AZEVEDOํㅗㄹ EDUARDO L. BORBA ${ }^{2,3}$ and CÁSSIO VAN DEN BERG ${ }^{1}$
}

(received: June 6, 2005; accepted: July 27, 2006)

\begin{abstract}
Evidence of natural hybridization and introgression in Bulbophyllum involutum Borba, Semir \& F. Barros and B. weddellii (Lindl.) Rchb. f. (Orchidaceae) in the Chapada Diamantina, Brazil, by using allozyme markers). Hybridization between B. involutum and B. weddellii (Orchidaceae) has been first observed in the Serra do Cipó, Minas Gerais State, Brazil, the hybrid being described as $B$. × cipoense Borba \& Semir. In this study, allozime electrophoresis was used to test the hypothesis of occurrence of hybridization between these two species, as suggested by morphological characters, in the Chapada Diamantina, Bahia State, Brazil. The lack of a diagnostic locus does not allow definite confirmation of the natural hybridization, although this hypotheses is reinforced by the absence of exclusive alleles in the putative hybrid individuals. The existence of several different genotypes points out to either population derived from multiple hybridization events or the hybrids produced offspring. Homozigosity in some morphologically intermediate individuals of alelles which are exclusive to $B$. involutum and high genetic similarity between them reinforce the hypotheses of introgression in $B$. involutum, but not in $B$. weddellii. Genetic variability observed in B. weddellii $\left(H_{\mathrm{e}}=0.21\right)$ and B. involutum $\left(H_{\mathrm{e}}=0.35\right)$ is high. Bulbophyllum weddellii and B. involutum presented very high genetic similarity values (0.94). These species, although vegetatively similar, have been placed in different sections based on floral morphology. The results suggest that these species may be more related than previously supposed.
\end{abstract}

Key words - Bulbophyllum, genetic variability, hybridization, introgression, Orchidaceae

RESUMO - (Evidência de hibridação e introgressão em Bulbophyllum involutum Borba, Semir \& F. Barros e B. weddellii (Lindl.) Rchb. f. (Orchidaceae) na Chapada Diamantina, Brasil, a partir de marcadores alozimáticos). Hibridação entre B. involutum e B. weddellii (Orchidaceae) foi observada pela primeira vez na Serra do Cipó, Estado de Minas Gerais, Brasil, o híbrido sendo descrito como B. $\times$ cipoense Borba \& Semir. Neste estudo, foi utilizada eletroforese de alozimas para testar a hipótese de ocorrência de hibridação entre estas espécies, como sugerido por caracteres morfológicos, na Chapada Diamantina, Estado da Bahia, Brasil. A falta de um locus diagnóstico não permite confirmação definitiva da hibridação natural, embora esta hipótese seja reforçada pela ausência de alelos exclusivos nos indivíduos supostamente híbridos. A existência de vários genótipos diferentes indica que ou a população é derivada de múltiplos eventos de hibridação, ou que os híbridos estão se reproduzindo. Homozigose em alguns indivíduos morfologicamente intermediários de alelos exclusivos à espécie $B$. involutum e a elevada similaridade genética entre eles reforçam a hipótese de introgressão em $B$. involutum, mas não em $B$. weddellii. A variabilidade genética observada em $B$. weddellii $\left(H_{\mathrm{e}}=0,21\right)$ e $B$. involutum $\left(H_{\mathrm{e}}=0,35\right)$ é elevada. Bulbophyllum weddellii e $B$. involutum apresentaram valor de similaridade genética muito elevado $(0,94)$. Estas espécies, embora vegetativamente muito similares, têm sido colocadas em diferentes seções baseado na morfologia floral. Os resultados encontrados sugerem que estas espécies são mais relacionadas do que previamente suposto.

Palavras-chave - Bulbophyllum, hibridação, introgressão, Orchidaceae, variabilidade genética

\section{Introduction}

Hybridization is common in several plant groups (Arnold 1994, Rieseberg 1995), including the

\footnotetext{
1. Universidade Estadual de Feira de Santana, Departamento de Ciências Biológicas, Laboratório de Sistemática Molecular de Plantas, Rodovia BR 116, km 03, 44031-460 Feira de Santana, BA, Brazil.

2. Universidade Federal de Minas Gerais, Instituto de Ciências Biológicas, Departamento de Botânica, 31270-901 Belo Horizonte, MG, Brazil.

3._Corresponding author: borba@gmx.net
}

Orchidaceae (van der Pijl \& Dodson 1966). It has been considered of great evolutionary importance, especially as a fast mode of evolution (Arnold 1994) or as a way to quickly increase the variability in parental species through introgression (Grant 1981, Klier et al. 1991). The main factors preventing hybridization in Orchidaceae are pre-pollination mechanisms such as pollinator specificity and phenological or mechanic barriers, while genetic barriers (post-pollination) between closely related species are usually weak or absent (van der Pijl \& Dodson 1966, Dressler 1981).

Borba \& Semir (1998a) described the hybrid Bulbophyllum $\times$ cipoense Borba \& Semir (figure 1, 2), 
between B. involutum Borba, Semir \& F. Barros (Bulbophyllum sect. Didactyle) and B. weddellii (Lindl.) Rchb. f. (B. sect. Xiphizusa) from Serra do Cipó, Minas Gerais State, Brazil. Their conclusions were based exclusively in morphological characters and reproductive biology data, therefore without the use of any kind of molecular markers to verify the hybridization hypothesis. Both putative parental species are sympatric and possess synchronized phenological events, and are intercompatible (Borba \& Semir 1998b, Borba et al. 1999). Despite the large differences in flower morphology, they present a relatively high similarity in the chemical composition of floral volatiles (Silva et al. 1999) and attract the same species of pollinators (Borba \& Semir 1998b). Borba \& Semir (1998a) suggested a series of barriers that could lead to the rarity of $B$. xcipoense and to the absence of further consequences in the parental species such as introgression or competition with the hybrids. So far, $B$. $\times$ cipoense has been the only case of natural hybridization registered for Bulbophyllum, despite the large number of species in the genus, $c a$. 1.100 species worldwide (Vermeulen 1991) and ca. 55 species in Brazil (Pabst \& Dungs 1975), and high sympatry.

In a recent orchid survey in Mucugê, Chapada Diamantina, Bahia State, Brazil, we found several morphologically intermediate individuals sympatric with $B$. involutum and $B$. weddellii, being similar to the previously described B. ×cipoense (Azevedo 2004). Furthermore, we also observed individuals morphologically intermediate between the putative hybrids and $B$. involutum, suggesting the occurrence of introgression in the latter species. The present work aims to investigate the hypothesis of natural hybridization between $B$. involutum and $B$. weddellii, and the occurence of introgression in the former, using allozyme markers.

\section{Material and methods}

We sampled leaves of 52 individuals of $B$. weddellii (Lindl.) Rchb.f. ( $n=20$; figure 3), B. involutum Borba, Semir \& F.Barros ( $n=18$; figure 4$)$ and intermediate individuals, including the putative hybrids (figure 5) and hypothesized introgressed individuals (figure 6); $n=14$, in rocky outcrops in the "campos rupestres" vegetation in the Parque Municipal de Mucugê, Bahia State. Samples were kept in liquid nitrogen until laboratory analysis. Vouchers are deposited in the herbarium at the Universidade Estadual de Feira de Santana (HUEFS; B. weddellii - C. Azevedo 188; B. involutum C. Azevedo \& J.Oliveira 149, C. Azevedo \& J. Oliveira 177; B. × cipoense - C. Azevedo \& E. Oliveira 182).
Leaf fragments were ground in $500 \mathrm{~mL}$ extraction buffer: $100 \mathrm{~mL}$ Tris- $\mathrm{HCl} 0.1 \mathrm{~mol} \mathrm{~L}^{-1} \mathrm{pH} 7.0,6.846 \mathrm{~g}$ sucrose, $0.6 \mathrm{~g}$ PVP (polyvinylpyrrolidone), $0.0372 \mathrm{~g}$ EDTA, $0.145 \mathrm{~g}$ BSA (bovine serum albumine), $0.13 \mathrm{~g}$ DIECA (sodium diethylcarbamate), $0.6 \mathrm{~g}$ Borax and $100 \mu \mathrm{L} \beta$-mercaptoethanol (modified from Sun \& Ganders 1990). Extracts were absorbed in Whatman number 3 paper and applied into Sigma starch gels. Three buffer systems were used: system 1 - electrode: boric acid $0.3 \mathrm{~mol} \mathrm{~L}^{-1}$, $\mathrm{NaOH} 0.06 \mathrm{~mol} \mathrm{~L}^{-1}$, pH 8.0; gel: Tris $0.01 \mathrm{~mol} \mathrm{~L}^{-1}$, pH 8.5; modified from Shaw \& Prasad (1970); system 2 electrode: citric acid $0.04 \mathrm{~mol} \mathrm{~L}^{-1}$ adjusted to $\mathrm{pH} 6.1$ with $\mathrm{N}$-(3aminopropyl)-morpholine; gel: electrode buffer diluted 1:20 (Clayton \& Tretiak 1972); system 3 - electrode: histidine $0.065 \mathrm{~mol} \mathrm{~L}^{-1}$ adjusted to $\mathrm{pH} 6.5$ with citric acid; gel: electrode buffer diluted 1:4; modified from Stuber et al. (1977). Standard gel electrophoresis was performed until the inner marker (bromophenol blue) reached $9 \mathrm{~cm}$ from the starting point, under the following running conditions: system 1: $30 \mathrm{~mA}$; system 2: $180 \mathrm{~V}$; system 3: $50 \mathrm{~mA}$. Ten enzyme systems were used: buffer system 1: esterase (EST; EC 3.1.1.1), acid phosphatase (ACP; EC 3.1.3.2), leucine aminopeptidase (LAP; EC 3.4.11.1), diaphorase (DIA; EC 1.8.1.4); buffer system 2: 6-phosphogluconic acid dehydrogenase (6PGD; EC 1.1.1.44); malate dehydrogenase (MDH; EC 1.1.1.37); buffer system 3: phosphoglucomutase (PGM; $\quad$ EC 2.7.5.1); phosphoglucoisomerase (PGI; EC 5.3.1.9), isocitrate dehydrogenase (IDH; EC 1.1.1.42), shikimic acid dehydrogenase (SKDH; EC 1.1.1.25). Staining protocols were slightly adjusted from Brune et al. (1998) (ACP, DIA, EST, LAP, SKDH), Corrias et al. (1991) (IDH, 6PGD, PGI) and Soltis et al. (1983) (PGM, MHD). Enzyme systems displaying more than one locus were numbered in ascending order from the least mobile locus. Alleles were numbered according to the relative mobility in relation to an allele of a $B$. weddellii individual present in all gels.

Allelic frequencies were obtained through manual scoring of banding patterns of homozygotes and heterozygotes. Genetic variability for each population was estimated with the following parameters: proportion of polymorphic loci $(P$; criterion 0.95$)$, mean number of alleles per locus $(A)$, observed $\left(H_{\mathrm{o}}\right)$ and expected $\left(H_{\mathrm{e}}\right)$ mean heterozygosity per locus. Genetic distance (unbiased genetic distance; Nei 1978) and genetic similarity (unbiased genetic identity; Nei 1978) matrices were calculated for the populations. Cluster analysis was performed from the genetic similarity matrix using the UPGMA algorithm. All analyses were performed with the software Biosys 1.0 (Swofford \& Selander 1989).

\section{Results}

Twelve loci in all ten systems tested presented activity, from which eight loci in seven systems (ACP, DIA, EST, IDH, LAP, MDH-1, MDH-2, 6PGD) presented good resolution and were included in the 
analyses. None of the observed loci (including PGI-1, PGI-2, PGM, SKDH) were diagnostic for Bulbophyllum weddellii (Lindl.) Rchb.f. and B. involutum Borba, Semir \& F.Barros (i.e. no locus presented only exclusive alleles for the species). None of the 14 intermediate individuals displayed any exclusive allele, although $B$. weddellii and $B$. involutum displayed, respectively, one and five exclusive alleles (table 1). Only LAP was monomorphic for all populations. We found up to five alleles per locus (EST), and a mean of 2.0 to 2.6 alelles per locus, and $38 \%$ to $88 \%$ polymorphic loci per population. Mean expected heterozygosity ranged from 0.21 to 0.35 in the three populations. Bulbophyllum involutum displayed the highest genetic variability,
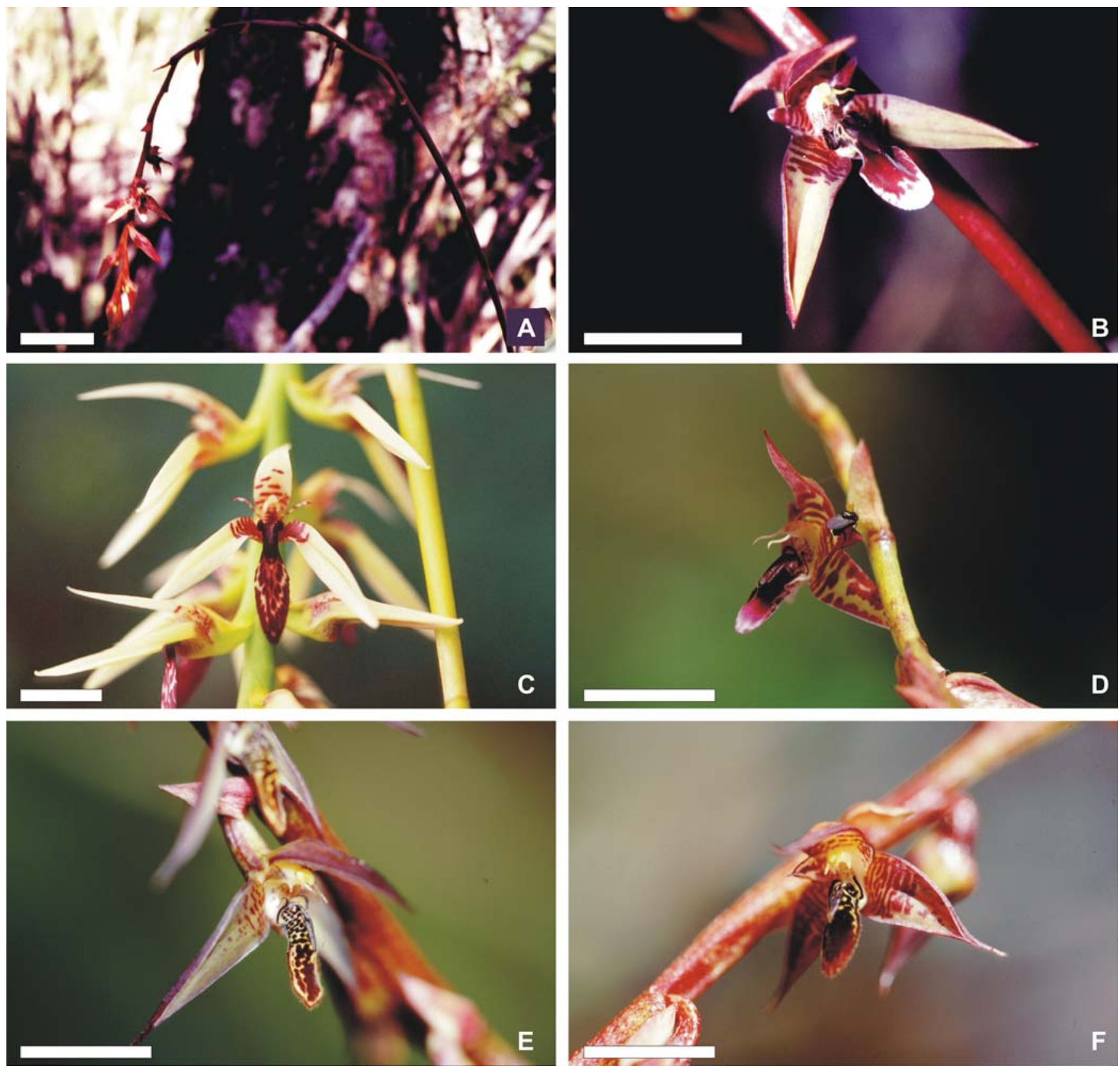

Figure 1-6. 1. Inflorescence of Bulbophyllum $\times$ cipoense Borba \& Semir. 2. Flower of the $B$. $\times$ cipoense holotype in the Serra do Cipó, Minas Gerais State, Brazil. 3. Flower of B. weddelli (Lindl.) Rchb.f. 4. Flower of B. involutum Borba, Semir \& F. Barros. 5. Flower of $B$. $\times$ cipoense. 6. Flower of individual of $B$. involutum presenting introgression, in Parque Municipal de Mucugê, Bahia State, Brazil. (1, 2: Borba 200, UEC; 3: Azevedo 188, HUEFS; 4: Azevedo \& Oliveira 149, HUEFS; 5: Azevedo \& Oliveira 182; 6: Azevedo \& Oliveira 177, HUEFS). Bars = $2.5 \mathrm{~cm}(1), 1.0 \mathrm{~cm}(2-6)$. 
whereas the intermediate individuals displayed the lowest (table 2).

From among the 14 intermediate individuals, 12 present a mixture of alleles present in both parentals in all loci. The other two individuals were homozygous in at least one locus for the alelle not present in $B$. weddellii (exclusive allele for $B$. involutum). There are also several different genotypes in the intermediate individuals.

Genetic similarity among the three populations was allways higher than 0.90 . The highest figures were found between $B$. involutum and the intermediate individuals, and the lowest between $B$. involutum e $B$. weddellii (table 3; figure 7).

\section{Discussion}

The absence of diagnostic loci between Bulbophyllum weddellii (Lindl.) Rchb. f. and B. involutum Borba, Semir \& F. Barros hinders us from a definite confirmation of natural hybridization between these two species in Mucugê. However, the fact that the intermediate individuals do not possess any exclusive alleles and that 12 out of 14 sampled individuals displayed alleles from both putative parents, allied to the morphological evidence, suggests the occurrence of natural hybridization between $B$. weddellii and $B$. involutum in Mucugê. The existence of several different genotypes in the intermediate individuals points out to an origin through multiple crossing events between $B$. weddellii and $B$. involutum. An alternative explanation is that the hybrids are reproducing.

Beyond color intermediacy, several other intermediate morphological characters can be found in B. × cipoense Borba \& Semir, in both Serra do Cipó and Mucugê: slightly falcate oval-lanceolate sepals (falcate lanceolate in $B$. weddellii and ovate in $B$. involutum), falcate oval-lanceolate petals with acute apex (falcate linear with acute apex in $B$. weddellii and ovate with obtuse apex in $B$. involutum), terminal lobe of the labellum with obtuse basis and slightly crenate margin (attenuate basis and smooth margin in $B$. weddellii and truncate to cordate basis and involute margin in $B$. involutum), angle between the labellum and the column of about $70^{\circ}\left(90^{\circ}\right.$ in $B$. weddellii and $45^{\circ}$ in B. involutum), and also intermediate length in all perianth parts (figure 1; Borba \& Semir 1998a, Azevedo 2004).

The highest genetic similarity between the intermediate individuals and $B$. involutum and the occurrence of two homozygous individuals for at least one locus for the exclusive allele of $B$. involutum reinforce the hypothesis of introgression of genes of $B$. weddellii into $B$. involutum, based originally only in

Table 1. Allelic frequencies in eight allozyme loci in populations of Bulbophyllum weddellii (Lindl.) Rchb. f., B. involutum Borba, Semir \& F. Barros and intermediate individuals (putative natural hybrids and putative introgressed individuals of $B$. involutum) in the Parque Municipal de Mucugê, Bahia state, Brazil. $n$ = sample size. (ACP = acid phosphatas, DIA = diaphorase, $\mathrm{EST}=$ esterase, $\mathrm{IDH}=$ isocitrate dehydrogenase, $\mathrm{LAP}=$ leucine aminopeptidase, $\mathrm{MDH}=$ malate dehydrogenase, 6PGD = 6-phosphogluconic acid dehydrogenase).

Locus/alelle B. weddellii Intermediate B. involutum

\begin{tabular}{|c|c|c|c|}
\hline \multicolumn{4}{|c|}{$\mathrm{ACP}$} \\
\hline 1 & 1.000 & 1.000 & 0.944 \\
\hline 2 & 0.000 & 0.000 & 0.056 \\
\hline$n$ & 18 & 14 & 18 \\
\hline \multicolumn{4}{|c|}{ DIA } \\
\hline 1 & 0.167 & 0.000 & 0.000 \\
\hline 2 & 0.611 & 0.750 & 0.667 \\
\hline 3 & 0.222 & 0.214 & 0.083 \\
\hline 4 & 0.000 & 0.036 & 0.250 \\
\hline$n$ & 18 & 14 & 18 \\
\hline \multicolumn{4}{|c|}{ EST } \\
\hline 1 & 0.294 & 0.208 & 0.118 \\
\hline 2 & 0.500 & 0.333 & 0.412 \\
\hline 3 & 0.059 & 0.125 & 0.324 \\
\hline 4 & 0.147 & 0.167 & 0.088 \\
\hline 5 & 0.000 & 0.167 & 0.059 \\
\hline$n$ & 17 & 12 & 17 \\
\hline \multicolumn{4}{|c|}{ IDH } \\
\hline 1 & 1.000 & 0.885 & 0.679 \\
\hline 2 & 0.000 & 0.115 & 0.321 \\
\hline$n$ & 14 & 13 & 14 \\
\hline \multicolumn{4}{|c|}{ LAP } \\
\hline 1 & 1.000 & 1.000 & 1.000 \\
\hline$n$ & 18 & 14 & 18 \\
\hline \multicolumn{4}{|c|}{ MDH-1 } \\
\hline 1 & 0.972 & 0.964 & 0.806 \\
\hline 2 & 0.028 & 0.036 & 0.194 \\
\hline$n$ & 18 & 14 & 18 \\
\hline \multicolumn{4}{|c|}{ MDH-2 } \\
\hline 1 & 0.139 & 0.000 & 0.028 \\
\hline 2 & 0.778 & 0.423 & 0.417 \\
\hline 3 & 0.083 & 0.577 & 0.556 \\
\hline$n$ & 18 & 13 & 18 \\
\hline \multicolumn{4}{|c|}{ 6PGD } \\
\hline 1 & 0.000 & 0.045 & 0.059 \\
\hline 2 & 1.000 & 0.955 & 0.912 \\
\hline 3 & 0.000 & 0.000 & 0.029 \\
\hline$n$ & 17 & 11 & 17 \\
\hline
\end{tabular}


Table 2. Genetic variability in eight allozyme loci in populations of Bulbophyllum weddellii (Lindl.) Rchb. f., B. involutum Borba, Semir \& F. Barros and intermediate individuals (putative hybrids and putative introgressed individuals of B. involutum), in the Parque Municipal de Mucugê, Bahia State, Brazil. ( $n=$ mean sample size; $A=$ mean number of alleles per locus; $\mathrm{P}=$ proportion of polymorphic loci; $H_{\mathrm{o}}=$ observed mean heterozygosity per locus; $H_{\mathrm{e}}=$ expected mean heterozygosity per locus (Nei 1978; unbiased estimate)). Standard deviations in parentheses. A locus was considered polymorphic if the most common allele frequency did not exceed 0.95 .

\begin{tabular}{lccccc}
\hline Population & $n$ & $A$ & $\mathrm{P}$ & $H_{\mathrm{o}}$ & $H_{\mathrm{e}}$ \\
\hline B. weddellii & $17.3(0.5)$ & $2.0(0.0)$ & 37.5 & $0.178(0.091)$ & $0.207(0.100)$ \\
intermediate & $13.1(0.4)$ & $2.3(0.5)$ & 50.0 & $0.215(0.085)$ & $0.262(0.102)$ \\
B. involutum & $17.3(0.5)$ & $2.6(0.4)$ & 87.5 & $0.324(0.096)$ & $0.351(0.086)$ \\
\hline
\end{tabular}

Table 3. Matrix of genetic identity and genetic distance between populations of Bulbophyllum weddellii (Lindl.) Rchb. f., B. involutum Borba, Semir \& F. Barros and intermediate individuals (putative hybrids and putative introgressed individuals of $B$. involutum), in the Parque Municipal de Mucugê, Bahia State, Brazil, using Nei (1978) unbiased genetic identity and unbiased genetic distance. Lower diagonal: genetic identity; Upper: genetic distance.

\begin{tabular}{lccc}
\hline Population & B. weddellii & Intermediate & B. involutum \\
\hline B. weddellii & - & 0.033 & 0.062 \\
intermediate & 0.967 & - & 0.009 \\
B. involutum & 0.940 & 0.991 & - \\
\hline
\end{tabular}

morphological characters (figure 1). The morphological uniformity observed in the population of $B$. weddellii in Mucugê points out to the absence of introgression in this species.

The situation found in the sampled populations are at odds with the original findings of Borba \& Semir (1998a) at Serra do Cipó. These authors found only one individual of $B$. $\times$ cipoense, and this plant presented a relatively high degree of sterility or self-incompatibility. They also did not find any evidence for introgression into any of the parental species. Borba \& Semir (1998a) depicted a series of weak barriers that could constitute a filter system ensuring the rarity of the hybrids and integrity of $B$. weddellii and $B$. involutum at Serra do Cipó: 1) the pollinators are the same, but the main pollinator of one species is the secondary of the other; 2 ) the pollinarium of $B$. weddellii does not enter on the stigmatic cavity of $B$. involutum (only the opposite occurs); 3) despite the species being intercompatible, hybrid seeds display low fertility; 4) parental species are sympatric but no syntopic; 5) the hybrid is selfincompatible or sterile and has inefficient pollination system. Similar mechanisms with several individually weak barriers have been observed elsewhere in the Orchidaceae (Romero \& Carnevali 1991).

On the other hand, Borba \& Semir (1998a) pinpointed the relativity of self-incompatibility and hybrid sterility in Orchidaceae, since due to the high number of ovules and pollen grains in the flowers and absence of endosperm in the seeds the chance of production of a few viable seeds in self-pollination or backcrosses to the parentals are high, especially in species with vegetative propagation that can live for hundreds of years such as Bulbophyllum (van der Pijl \& Dodson 1966). Once the first sterility barriers are broken, complete fertility can be attained in posterior hybrid generations, and could lead to hybrid stability and speciation (Grant 1981, Rieseberg 1995). Apparently this sort of reproductive success still does not occur in B. ×cipoense in Serra do Cipó (Borba \& Semir 1998a), but there are indications that it could occur in the

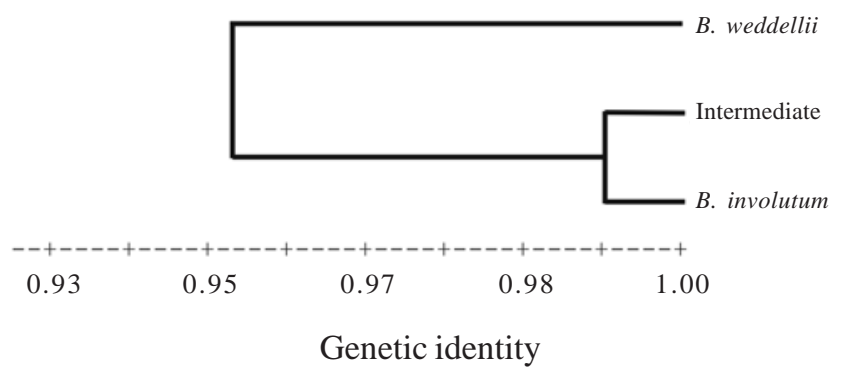

Figure 7. Dendrogram showing the phenetic relationships among the populations of Bulbophyllum weddellii (Lindl.) Rchb. f., B. involutum Borba, Semir \& F. Barros and intermediate individuals (putative hybrids and putative introgressed individuals of $B$. involutum), in Parque Municipal de Mucugê, Bahia State, Brazil. Constructed using the matrix of genetic identities through Nei (1978) unbiased genetic identity and UPGMA algorithm. 
individuals of Mucugê, at least through backcrosses with B. involutum.

Genetic variability observed in the populations studied is relatively high, especially considering that these species are self-compatible and pollinated by flies that usually remain for a long time in the flowers, that could favor self-pollination (Borba \& Semir 1998b, Borba et al. 1999, Hamrick \& Godt 1990). According to Borba \& Semir (1999), self-pollination in these species is decreased by mechanic floral barriers, and the mechanism displayed by $B$. involutum is more efficient than that of $B$. weddellii. This statement is reinforced by our results. Similar results have been found in other fly-pollinated orchid groups in the Brazilian "campos rupestres” (Borba \& Semir 2001, Borba et al. 2001).

Another unexpected result was the very high genetic similarity between $B$. weddellii and $B$. involutum. The figures found are usually observed only between conspecific populations or closely related species (Crawford 1989, Borba et al. 2001). However, these species possess rather distinct flower morphology, reason by which, despite being vegetatively almost indistinguishable, they have been placed in different sections of the genus (Pabst \& Dungs 1975). High genetic similarity has also been reported between $B$. weddellii and B. ipanemense Hoehne (Farinaci 2001), the latter belonging to the same section and similar to $B$. involutum in both floral and vegetative traits (Pabst \& Dungs 1975, Borba \& Semir 1998b). On the other hand, Brazilian species of Bulbophyllum belonging to different sections and distinct in both vegetative and floral characters have been displaying much lower genetic similarity values (Azevedo et al. unpublished data). Those results suggest that $B$. weddellii might be more closely related to $B$. involutum and $B$. ipanemense than previously supposed.

Acknowledgements - This paper is part of the M.Sc. of C.O. Azevedo, supported by a scholarship from Fapesb (Fundação de Apoio à Pesquisa do Estado da Bahia). E. L. Borba and C. van den Berg are supported by a grant (PQ2) from CNPq (Conselho Nacional de Desenvolvimento Científico e Tecnológico, Brazil).

\section{References}

ARNOLD, M.L. 1994. Natural hybridization and Louisiana irises: defining a major factor in plant evolution. BioScience 44:141-147.

AZEVEDO, C.O. 2004. A família Orchidaceae no Parque Municipal de Mucugê, Bahia, Brasil. Dissertação de mestrado, Universidade Estadual de Feira de Santana, Feira de Santana.
BORBA, E.L. \& SEMIR, J. 1998a. Bulbophyllum × cipoense (Orchidaceae), a new natural hybrid from the Brazilian 'campos rupestres'. Lindleyana 13:113-120.

BORBA, E.L. \& SEMIR, J. 1998b. Wind-assisted fly pollination in three Bulbophyllum (Orchidaceae) species occurring in the Brazilian campos rupestres. Lindleyana 13:203-218.

BORBA, E.L. \& SEMIR, J. 1999. Temporal variation in pollinarium size in species of Bulbophyllum: a different mechanism preventing self-pollination in Orchidaceae. Plant Systematics and Evolution 217:197-204.

BORBA, E.L. \& SEMIR, J. 2001. Pollinator specificity and convergence in fly-pollinated Pleurothallis (Orchidaceae) species: a multiple population approach. Annals of Botany 88:75-88.

BORBA, E.L., SHEPHERD, G.J. \& SEMIR, J. 1999. Reproductive systems and crossing potential in three species of Bulbophyllum (Orchidaceae) occurring in the Brazilian 'campos rupestres' vegetation. Plant Systematics and Evolution 217:205-214.

BORBA, E.L., FELIX, J.M., SOLFERINI, V.N. \& SEMIR, J. 2001. Fly-pollinated Pleurothallis (Orchidaceae) species have high genetic variability: evidence from isozymes markers. American Journal of Botany 88:419-428.

BRUNE, W., ALFENAS, A.C. \& JUNGHANS, T.G. 1998. Identificações específicas de enzimas em géis. In Eletroforese de isoenzimas e proteínas afins: fundamentos e aplicações em plantas e microorganismos (A.C. Alfenas, ed.). Editora da Universidade Federal de Viçosa, Viçosa, p.201-328.

CLAYTON, J. \& TRETIAK, D. 1972. Amine-citrate buffers for $\mathrm{pH}$ control in starch gel electrophoresis. Journal of Fisheries Research Board of Canada 29:1169-1172.

CORRIAS, B., ROSSI, W., ARDUINO, P., CIANCHI, R. \& BULLINI, L. 1991. Orchis longicornu Poiret in Sardinia: genetic, morphological and chorological data. Webbia 45:71-101.

CRAWFORD, D.J. 1989. Enzime electrophoresis and plant systematics. In Isozymes in plant biology (D.E. Soltis \& P.S. Soltis, eds.). Dioscorides Press, Portland, p.146-164.

DRESSLER, R.L. 1981. The orchids: natural history and classification. Harvard University Press, Cambridge.

FARINACI, J.S. 2001. Variabilidade genética em algumas espécies de Bulbophyllum Thouars (Orchidaceae) de campos rupestres. Dissertação de mestrado, Universidade Estadual de Campinas, Campinas.

GRANT, V. 1981. Plant speciation, $2^{\text {nd }}$ ed. Columbia University Press, New York.

HAMRICK, J.L. \& GODT, M.J. 1990. Allozyme diversity in plant species. In Plant population genetics, breeding, and genetic resources (A.H.D. Brown, M.T. Clegg, A.L. Kahler \& B.S. Weir, eds.). Sinauer, Sunderland, p.43-63.

KLIER, K., LEOSCHKE, M.J. \& WENDEL, J.F. 1991. Hybridization and introgression in the white and yellow ladyslipper orchids (Cypripedium candidum and Cypripedium pubescens). Journal of Heredity 82:305-318. 
NEI, M. 1978. Estimation of average heterozygosity and genetic distance from a small number of individuals. Genetics 89:583-590.

PABST, G.F.J. \& DUNGS, F. 1975. Orchidaceae brasilienses, v.1. Kurt Schmersow, Hildeshein.

RIESEBERG, L.H. 1995. The role of hybridization in evolution: old wine in new skins. American Journal of Botany 82:944-953.

ROMERO, G.A. \& CARNEVALI, G. 1991. Catasetum natural hybrids from southern Venezuela - 3. Catasetum $\times$ roseoalbum (Hook.) Lindley and C. ×wendlingeri Foldats. American Orchid Society Bulletin 60:770-774.

SHAW, C.R. \& PRASAD, R. 1970. Starch gel electrophoresis of enzimes - a compilation of recipes. Biochemical Genetics 4:297-320.

SILVA, U.F., BORBA, E.L., SEMIR, J. \& MARSAIOLI, A.J. 1999. A simple solid injection device for the analyses of Bulbophyllum (Orchidaceae) volatiles. Phytochemistry 50:31-34.
SOLTIS, D.E., HAUFLER, C.H., DARROW, D.C. \& GASTONY, GJ. 1983. Starch gel electrophoresis of ferns: a compilation of grinding buffers, gel and electrode buffers, and staining schedules. American Fern Journal 73:9-27.

STUBER, C.W., GOODMAN, M.M. \& JOHNSON, F.M. 1977. Genetic control and racial variation of b-glucosidase isozymes in maize (Zea mays L.). Biochemical Genetics 15:383-394.

SUN, M. \& GANDERS, F.R. 1990. Outcrossing rates and allozyme variation in rayed and rayless morphs of Bidens pilosa. Heredity 64:139-143.

SWOFFORD, D.L. \& SELANDER, R.B. 1989. Byosys-1: computer program for the analysis of allelic variation in population genetics and biochemical systematics. Illinois Natural History Survey, Champaign.

VAN DER PIJL, L. \& DODSON, C.H. 1966. Orchid flowers: their pollination and evolution. University of Miami Press, Coral Gables.

VERMEULEN, J.J. 1991. Orchids of Borneo, v.2. Bulbophyllum. Royal Botanic Gardens, Kew. 